\title{
Taking a Closer Look
}

\section{LGBTQ Characters in Books for Intermediate-Grade Children}

TADAYUKI SUZUKI AND BARBARA FIEHN

$\mathrm{S}$ ome years ago a student in our graduate course on children's literature said, "We have looked at a lot of picture books with LGBTQ (Lesbian, Gay, Bisexual, Transgendered, and Questioning) themes and characters, but are there any books for intermediate-level elementary students? There aren't any listed in our textbook." Until hearing the question from this student, we had never thought about the availability of LGBTQ books for intermediate-grade children. However, this question began a search lasting several years and resulted in the book list at the end of this article. In 2012, Jamie Campbell Naidoo's book Rainbow Family Collections affirmed the experiences we had locating LGBTQ books for intermediate-level elementary students. ${ }^{1}$ This book covers LGBTQ media for preschool through grade six published through 2011, as a result, we have limited this article to books published since 2011. This article also discusses why locating these titles is often difficult and why the books need to be available to students.

\section{Locating LGBTQ Books}

Why is it difficult to locate LGBTQ books for intermediategrade children? "There's virtually nothing in the middle," says j wallace skelton, referring to the numerous LGBTQ books for primary and middle/high school grades. ${ }^{2}$ Complicating finding the few books published for this age group are three things: the predominance of less widely distributed independent presses, the limited coverage by review sources, and retrieval problems with current subject cataloging.

\section{Independent Publishers and Publicity}

Malinda Lo's research indicates 30 percent of the publishers for young adult LGBTQ literature are independent presses. ${ }^{3}$ If this is also true for elementary titles, then at least 30 percent of the LGBTQ children's titles also come from independent presses. Titles from independent presses often lack the same level of publicity as books from large publishing houses; thus they get less notice.

Jewell Gomez says, "I'd love to see better marketing of LGBTQ books so they don't just disappear." ${ }^{4}$ Lacking publicity campaigns, LGBTQ titles are less likely to be noticed by reviewers; therefore, the books do not make it into many selection tools. With the advent of Internet social media sites such as the blog Gay-Themed Picture Books for Children and independent
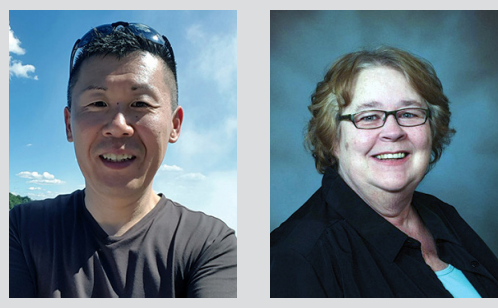

Tadayuki Suzuki is an associate professor in the Literacy Department, State University of New York College at Cortland, in Cortland, New York. He teaches both undergraduate and graduate literacy courses. His academic interests are literacy methods, teaching ESL, and multicultural education, especially the use of multicultural literature. Barbara Fiehn, MS, EdD, is an Associate Professor of Library Media Education at Western Kentucky University. Following thirty years as a school librarian, consultant, and media services coordinator, she taught in library media education at Minnesota State University at Mankato and Northern Illinois University. She has also served on the ALA Intellectual Freedom committee. 
press websites, children's LGBTQ titles are getting easier to find than previously. ${ }^{5}$

Booklist and School Library Journal frequently comment on the LGBTQ content; however, secondary LGBTQ characters are less often mentioned. Those writing reviews are either unaware of the importance of this information or uncomfortable with mentioning LGBTQ content. A good example is the recently published The Marvels by Brian Selznick. ${ }^{6}$ While reading reviews from three different sources, the Booklist review specifically used the word "gay" in referring to Joseph's uncle but did not refer to his beloved dying of AIDS. ${ }^{7}$ The Kirkus review remarked only that the uncle's beloved died of AIDS, ${ }^{8}$ and the School Library Journal review made no mention or allusion to the uncle's sexual orientation, his beloved, or AIDS. ${ }^{9}$ If a person read only the third review, they would not know the book included a gay character.

\section{Book Awards}

A second reason for lack of awareness is librarians and teachers look to book awards as a guide when selecting books. Awards for children's LGBTQ titles are relatively new and have yet to gain much recognition outside the LGBTQ community. The first Lambda Literary Award to a children's or young adult title was given in 1990. The Amelia Bloomer List, established in 2002, is for high-quality fiction and nonfiction books with strong feminist content (https://ameliabloomer.wordpress.com). While not specific LGBTQ, the books on the list frequently include gender nonconforming or gender fluid characters, which are part of the critical LGBTQ identity.

The Rainbow Book List, established in 2007, is a "best of the year list" highlighting books that portray LGBTQ content for children through age eighteen (http://glbtrt.ala.org/rainbow books/rainbow-books-lists). The newest award, established in 2010, is the Children's and Young Adult Literature Award within the larger Stonewall Book Awards (www.ala.org/glbtrt/award/ honored).

\section{Subject Cataloging}

A third, and perhaps the most difficult, barrier to locating LGBTQ titles is subject indexing. Searching in any standard index, such as World Catalog, Books in Print, Book Review Index, or library catalogs in general, generate few, if any, usable LGBTQ results. According to Naidoo, ${ }^{10}$ and supported by Schrader and Johnson, ${ }^{11}$ subject access to LGBTQ children's titles is fruitless. A major rule in library subject cataloging is to assign subject headings based on the content subject of the material.

Children's fiction books with LGBTQ characters are frequently not about homosexuality. For example, the book The Manny Files by Christian Burch is about a male nanny. ${ }^{12}$ The story is about how the Manny (male nanny) becomes part of the family. While there are subtle hints throughout the book that the Manny and the family's Uncle Max are forming a close relationship, it is not until the end of the book that the relationship is identified as love. World Catalog assigned the following subjects:

- Nannies -- Fiction.

- Sex role -- Fiction.

- Self-confidence -- Fiction.

- Family life -- Fiction.

- Brothers and sisters -- Fiction.

These subjects do not lead the searcher to LGBTQ materials. The most fruitful subject from the above list would be Sex role -- Fiction. Such a search returns an overwhelming number of items, but few will be relevant to the LGBTQ community. Johnson and Naidoo maintain that searching major indexes and library catalogs for LGBTQ books will remain problematic until indexing processes are changed. ${ }^{13}$ Library records must begin making use of key words and tagging to identify LGBTQ materials. Naidoo suggests using phrases that are more descriptive and consistently applied would help identify desired books such as the following:

- children of gay parents

- same-sex parents

- lesbian mothers

- gay fathers

- lesbian characters

- gay characters ${ }^{14}$

Perseverance, some luck, and good searching skills bring results when searching for LGBTQ books for intermediate-grade children. Some may question why looking for LGBTQ books is important when there are thousands of other easily accessible books for this age group published each year. Many misconceptions regarding LGBTQ issues exist, such as sexual orientation is a choice, elementary age children do not identify as LGBTQ, books with LGBTQ characters have sex in them, or there are no LGBTQ families or children in our school. Not only children but also adults need more information; teachers and librarians should take the initiative.

Easily identifying LGBTQ books is important to help schools and public libraries support and celebrate the diverse communities. Schools have a responsibility to provide students with opportunities to explore literature from multiple points of view. Diverse family constructs are no longer an exception; Education Week reports LGBT parents are raising nearly 210 million children. ${ }^{15}$ Additionally, many educators, including Short and Temple, who support multiculturalism, advocate that all children should see themselves and their families in books 
they read. ${ }^{16}$ If teachers are to meet the needs of children in their classrooms and provide their students with learning opportunities about the larger world, then all minority groups should be included in the literature available in school classrooms and libraries. Excluding any group is a disservice to all learners.

Derman-Sparks and Edwards indicate children come to school with a perception of their family as an extension of themselves; ${ }^{17}$ however, they are also curious about other family makeups. Children initially may view any family that is different from their own with curiosity. If only some families are validated, children may question if other family structures are acceptable.

Exclusionary experiences contribute to the name-calling and bullying of any child who is outside or perceived as outside the normative expectation. When classroom materials and curricula exclude a group of people, the group becomes marginalized. Those who are marginalized are at risk for bullying. Additionally, research by Manning indicates childhood and adolescence are the times when the introduction of diverse topics is appropriate. ${ }^{18}$ Therefore, to provide an inclusive environment for children from families with LGBTQ members, it is important that schools include LGBTQ books in their classrooms and libraries.

\section{IGBTO Books 2011 to Present}

Identifying criteria for evaluating books for children is not difficult. Authors of children's literature textbooks such as Short and Temple have discussed evaluative criteria at length. ${ }^{19}$ Criteria specific to LGBTQ titles is added to basic children's literature evaluative criteria as a foundation for selecting and evaluating books. Such criteria are found in the work of Naidoo, ${ }^{20}$ the American Library Association's Gay, Lesbian, Bisexual and Transgender Round Table document, ${ }^{21}$ and Lesbian and Gay Voices: An Annotated Bibliography and Guide to Literature for Children and Young Adults by Frances Ann Day. ${ }^{22}$

In reviewing the books listed below, the following simplified criteria were developed using the above resources.

- Age appropriate, meaning the writing style and content maturity, as well as the measures of reading and interest levels, such as Lexile number, indicates the book was intended for intermediate grade students.

- Good story is the key to keeping a reader interested. The characters, plot, setting, and dialogue engage the reader.

- LGBTQ character trait is a normal part of the character. The story is not about being LGBTQ but is a descriptor similar to the character being left handed or green eyed. If the plot includes LGBTQ issues, they are treated in a realistic manner.

The books on the following list were evaluated as meeting the standard children's literature and the LGBTQ literature criteria. For discussion purposes, the following groupings are used:
- books with LGBTQ main characters;

- books with LGBTQ secondary characters;

- books about transgender people; and

- nonfiction/informational books including LGBTQ identity.

\section{Books with LGBTQ Main Characters}

Two fiction books with LGBTQ main characters, both written by Tim Federle, were identified. Authors and publishers need to consider and support the writing of more books for the LGBTQ genre for this age group since as stated by Mallon and DeCrescenzo "gender identity develops in children by the age of 3."23

Federle, Tim. Better Nate than Ever. New York: Simon \& Schuster Books for Young Readers. 2013.304p.

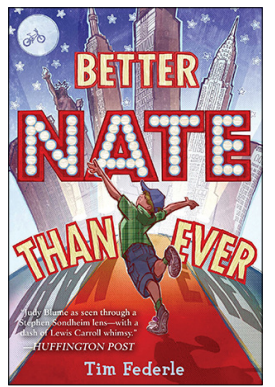

Four-foot-eight-inches, almost fourteen, not athletic, bullied at school, overshadowed by his sports star brother, that's Nate Foster. He and his best friend Libby are Broadway musical fans. They act out Broadway musicals in Libby's basement. Nate's big dream is to be on Broadway. Together, Libby and Nate make Nate's dream come true through a trip to New York to audition for E.T. the Musical. A 2014 Stonewall Book Award Honor title, Better Nate than Ever is a delightful story of a young teen looking to validate himself in a community and family that does not appreciate his uniqueness. Positively reviewed in Booklist. Lexile 930, age range 9-13, grade level 4-8.

Federle, Tim. Five, Six, Seven, Nate! New York: Simon \& Schuster Books for Young Readers. 2014.320p.

Five, Six, Seven, Nate! begins shortly after Nate's auditions for E.T. the Musical. As the book opens, Libby and Nate are in his bedroom, not really packing Nate's bags for New York. Yes, he is going back to live with his Aunt Heidi. Will New York theater world be all he hopes? The story is engaging and easy to read and is a totally fun read. Nate solidifies his self-identification of being gay. However, this is not a story about being

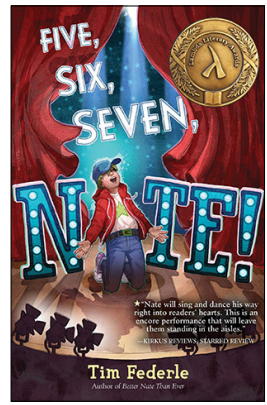
gay; it is about living a dream of being on Broadway in musical theater, growing up, and interpersonal relationships. Positively reviewed in Booklist, Lexile 710, age range 10-14, grade level 5-9.

\section{Books with LGBTQ Secondary Characters}

Secondary LGBTQ characters tend to be parents, uncles, neighbors, or good friends. Finding a children's book with an LGBTQ 
aunt is rare. There are six titles containing secondary LGBTQ characters.

Gennari, Jennifer. My Mixed-Up Berry Blue Summer. Boston, MA: Houghton Mifflin. 2012. 128p.

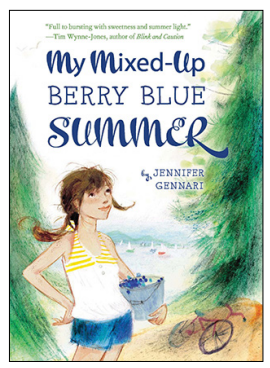

There is just nothing quite like New England blueberries, especially when they are made into a pie. Twelve-year-old June Farrel has a talent for making pies. She hopes to win the pie-making contest at the fair. The blueberries she found high above Lake Champlain are sure to be perfect for her pie; however, there are complications. The upcoming wedding of her mother and her partner brings prejudice and harassment from anti-gay marriage folks as well as from June's friends and classmates. Positively reviewed in School Library Journal and Booklist, Lexile 750, age range 10-12, grade level 5-7.

\section{Levy, Dana A. The Misadventures of the Family Fletcher. New} York: Delacorte Press. 2014. 272p.

The Fletcher family is as normal as any family can be when it contains four boys, a cat, a dog, and an imaginary cheetah. Written in third-person narrative, the chapters rotate between stories of each boy's school year. Tying the chapters together are the boys' common experiences of celebrations, family vacations, and the supportive guidance of their fathers. Starred reviews in

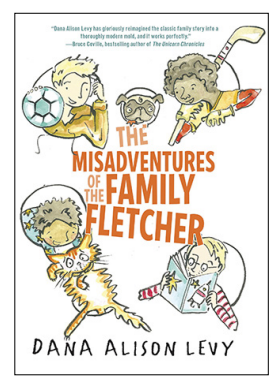
School Library Journal and Kirkus, positive review in Horn Book, Junior Library Guild selection, Lexile 570, age range 9-12, grade level 4-7.

Mackler, Carolyn. Best Friend Next Door. New York: Scholastic. 2015.229p.

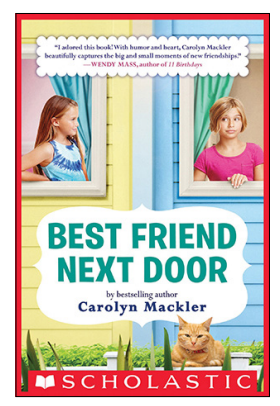

Hannah's best friend has moved away and she is heartbroken, but when Hannah gets to know the new girl, Emme, who moves in next door, life takes on a whole new look. Adjusting to life changes, the two girls tell their stories in alternating chapters, while Hannah's mother and father and Emme's two mothers are supportive and caring. Positively reviewed in School Library Journal and Kirkus, Lexile 670, age range 8-11, grade level: 3-6.

Selznick, Brian. Illus. by the author. The Marvels. New York: Scholastic. 2015.672p.

The Marvels is two interlinked stories, one told through magnificent line drawings, and one in text, which draw the reader into the world of the theater and into the museum-like home of Uncle Albert. The text story tells of Joseph, who runs away from boarding school to find his Uncle Albert. As the story develops, the reader discovers, along with Joseph, how the two stories are connected. Uncle Albert is the gay character. Starred reviews: Kirkus, SLJ, and Booklist, Lexile 770, age range 8-12 years, grade level 3-7.

Urban, Linda. The Center of Everything. Boston, MA: Harcourt. 2013. 208p.

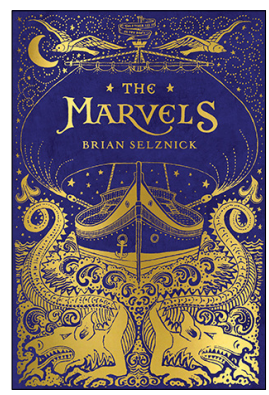

A story filled with circular references shows the reader how events cause ripples. This is a short book, plot driven, with a strong voice centering on twelve-year-old Ruby. The story emerges through flashbacks, with all the action occurring in one day. The resolution is satisfying, and Ruby and her two best friends, Lucy and Nero, act and sound like tweens. The LGBTQ characters are Lucy's fathers. Positively reviewed by all major review sources, it was a starred review by Booklist, Lexile 830, age range 9-12, grade level 4-7.

Yeh, Kat. The Truth about Twinkie Pie. New York: Little, Brown, and Company. 2015. 208p.

After winning a million dollar recipe contest, DiDi and GiGi transplant themselves from a South Carolina trailer park to an upscale Long Island, New York, community. DiDi deals with being sister and mother to tween GiGi, who is trying to reinvent herself as she enters a new school while learning lessons about the meaning of family and friendship. Recipes, tied to the story line, are inserted between many

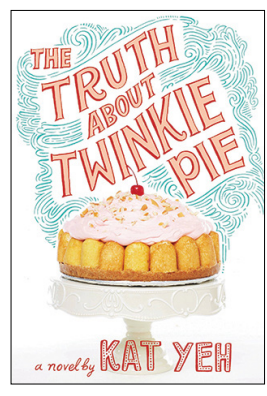
of the chapters. The recipes mark moments of growth. The LGBTQ character is a boy, who as the book ends, begins the process of self-acknowledgment. Positively reviewed in Booklist, Kirkus, School Library Journal, and VOYA, Lexile 730, age range 8-12, grade level 3-7.

\section{Books about Transgender People}

Transgender people are those who behave in a manner that is outside the expectations of a society for a specific observable sex gender. Transgender book characters provide readers with alternatives to such stereotypical gender roles and provide a window to understanding for readers.

\section{Gino, Alex. George. New York: Scholastic. 2015. 240p.}

Ten-year-old George knows she is and always has been her female self, Melissa, but she has never told anyone. Told in the first person, the story is about normal school and life experiences colored by the knowledge that George is 


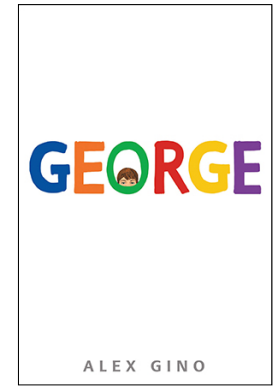

concealing her very important secret. As the story progresses, George tells her best friend Kelly and later her family. Starred reviews in School Library Journal, Kirkus, and Booklist, Lexile 790, age range 8-12, grade level 3-7. This book won the 2015 Stonewall Book Award.

Polonsky, Ami. Gracefully Grayson. New York: Hyperion. 2014. 256p.

Grayson is struggling to fit in and deals alone with his feelings that arise from being born a boy, but always feeling he was a girl. Grayson is an orphan who has lived with his aunt and uncle since he was a young child. This book has the voice of a preteen. The reader walks in Grayson's shadow cheering him on, wishing he would confide in someone. This is the first book with a transgendered main character

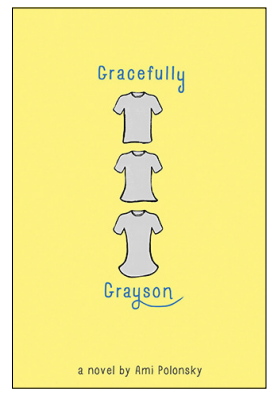
for tweens. Positively reviewed in Kirkus, Booklist, and School Library Journal, Lexile 720, age range 10-14, grade level 5-9.

\section{Nonfiction Books Including LGBTQ Identity}

Dana Rudolph says, “The fact is, children's books about real LGBT people and LGBT civil rights events are even scarcer than children's LGBT-inclusive fiction." ${ }^{24}$ The books reviewed in this section openly address people who are LGBTQ or issues of LGBTQ people and communities. Within this category are books with social science perspectives, issues of puberty, and biographies.

Kingston, Anna. Respecting the Contributions of LGBT Americans. New York: PowerKids Press. 2013. 24p.

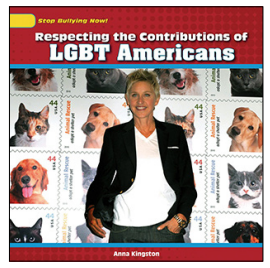

Each chapter is a two-page spread covering the history and contributions of lesbian, gay, bisexual, and transgender Americans, including Maurice Sendak, Harvey Milk, Chaz Bono, and Ellen DeGeneres. The book also contains a glossary, index, and websites. Each topic is handled appropriately for the age level, discussed briefly but with an adequate amount of information for a good introduction to the issues. It is now outdated, but still historically accurate. The writing is clear and easy to understand. Positively reviewed in Booklist, Lexile not available, age range 7-11, grade level 3-6.

Plaisted, Caroline. Boy Talk: A Survival Guide to Growing Up. Mankato, MN: QEB Pub. 2011.48p.

Intended for the pre-adolescent, this title uses a frank but short question-and-answer format, which covers almost everything upper elementary or early middle-school boys or perhaps curious girls could want to know about male puberty. A page dealing with crushes discusses feelings toward both girls and boys. Illustrations are cartoonish with text backed in colorful blocks. The narrative voice is supportive, reinforcing that everything is normal. A table of contents, glossary, and an index are helpful additions. Enthusiastically reviewed by Booklist, Lexile not available, age range $9-13$, grade level $4-8$.

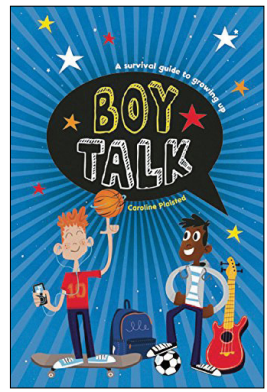

Silverberg, Cory and Fiona Smyth. Sex Is a Funny Word. New York: Seven Stories Press. 2015. 160p.

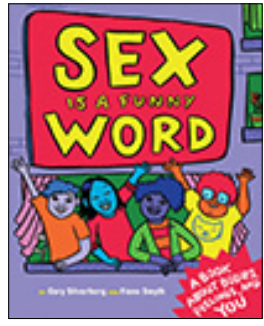

This book provides an affirming introduction for children to an exploration of relationships, gender identity, and growing sexual awareness. Included are proper words for body parts, and a section on masturbation. The book includes LGBTQ identities as a normal part of the discussion. Positively reviewed in Kirkus, Lexile

710 , age range $7-10$, grade level $2-5$. This book was named a 2015 Stonewall Honor Book.

Stuckey, Rachel. Straight Talk about Sexual Orientation and Gender Identity. New York: Crabtree. 2015. 48p.

This book approaches the topic of sexual orientation and gender identity in reassuring and nonjudgmental ways. True to the series objectives, this brief book introduces the issues in a factual manner. A table of contents, other resources, and glossary help the child seeking specific information. Positively reviewed in Booklist, Lexile 930, age range 10-14, grade level 5-7.

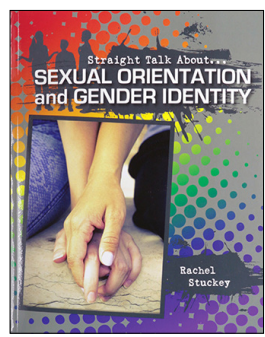

\section{Conclusions and Implications}

Books for intermediate grades with LGBTQ characters do exist and have existed for many years. However, it still takes a bit of searching to find them. Rainbow Family Collections is a primary source for locating the books published through 2011. This article identifies and discusses titles published since 2011, which are strong examples of quality LGBTQ literature. These books are similar in story content to many non-LGBTQ content books written for the upper elementary age level. The inclusion of LGBTQ books in school library collections is important. Pat Griffin suggests it is a step toward welcoming all students, staff, and families as valued members of the school community. ${ }^{25}$ Moving these books out of the library and into the classroom is a next big step.

Therefore school administrators, librarians, and teachers need to work collaboratively to discuss and plan for the inclusion of LGBTQ books in the school libraries and even in the 
instructional curricula. Kay Emfinger maintains, "We must make an honest assessment of our own practices, beliefs, and attitudes. For we as teachers, can change only ourselves. Transformation stems from self-reflection and knowledge gained from interfacing with resources for teachers." ${ }^{26}$ From this collaborative effort, teachers can create a more interactive literacy-learning environment such as a literature circle, a theme analysis, and/or a grand conversation, which further supports the unique characteristics of all students and their families within the school. $₫$.

\section{References}

1. Jamie C. Naidoo, Rainbow Family Collections (Santa Barbara, CA: Libraries Unlimited. 2012).

2. j wallace skelton as quoted in Neda Ulaby, “'George’ wants you to know she is really Melissa," Morning Edition, last modified Aug. 27, 2015, www.npr.org/2015/08/27/ 434277989/-george-wants-you-to-know-she-s-really -melissa.

3. Malinda Lo, "I Have Numbers! Stats on LGBT Young Adult Books Published in the U.S.," last modified Sept. 15, 2011, www.malindalo.com/2011/09/i-have-numbers-stats-on -lgbt-young-adult-books-published-in-the-u-s.

4. Jewell Gomez as quoted in Seth Dellon, "LGBTQ Publishing: An LGBTQ Publishing Wish List,” last modified May 23, 2015, www.publishersweekly.com/pw/by-topic/ new-titles/adult-announcements/article/66737-lgbtq -2015-an-lgbtq-publishing-wish-list.html.

5. Patricia Sarles, "Gay-Themed Picture Books for Children," accessed Oct. 21, 2015, http://booksforkidsingayfamilies .blogspot.com.

6. Brian Selznick, The Marvels (New York: Scholastic, 2015).

7. Sarah Hunter, “The Marvels,” Booklist, published July, 2015, www.booklistonline.com/The-Marvels-Brian -Selznick/pid=7578533.

8. “The Marvels," Kirkus, June 16, 2015, www.kirkusreviews .com/book-reviews/brian-selznick/the-marvels.

9. Carol A. Edwards, “The Marvels,” School Library Journal, August 4, 2015, accessed Oct.15, 2015, www.slj.com/ 2015/08/reviews/books/the-marvels-by-brian-selznick -slj-review/\#.

10. Naidoo, Rainbow Family Collections.

11. Alvin M Schrader, "I Thought I'd Find Myself at the Library: LGBTQ Services \& Collections in Public and School Libraries," PNLA Quarterly 72, no. 1 (Fall 2007); Matt Johnson, “Gay, Lesbian, Bisexual, and Transgender
Subject Access: History and Current Practice," (MLS thesis, Queens College, 2007), www.lib.washington.edu/msd/ norestriction/b58062361.pdf.

12. Christian Burch, The Manny Files (New York: Atheneum, 2006).

13. Johnson, “Gay, Lesbian, Bisexual, and Transgender Subject Access”; Naidoo, Rainbow Family Collections.

14. Ibid.

15. "Same-Sex Parents: A Statistical Snapshot" Education Week (Bethesda, MD) 34, no. 29 (October 21, 2015), www .edweek.org/ew/section/multimedia/same-sex-parents -a-statistical-snapshot.html.

16. Kathy Short, Carol Lynch-Brown, and Carl M. Tomlinson, Essentials of Children's Literature, 8th ed. (Boston, MA: Allyn \& Bacon, 2013); Charles A. Temple, Miriam A. Martinez, and Junko Yokota, Children's Books in Children's Hands: An Introduction to Their Literature (Boston, MA: Allyn \& Bacon. 2010).

17. Louise Derman-Sparks and Julie O. Edwards, Anti-bias Education for Young Children and Ourselves (Washington, DC: National Association for the Education of Young Children, 2010).

18. M. Lee Manning, "Developing Responsive Multicultural Education for Young Adolescents," Childhood Education, 76, no. 2 (1999).

19. Short, Essentials of Children's Literature; Temple, Children's Books in Children's Hand.

20. Naidoo, Rainbow Family Collections.

21. American Library Association's Gay, Lesbian, Bisexual and Transgender Round Table, "What to Do until Utopia Arrives,” 2013, www.ala.org/glbtrt/popularresources/ utopia.

22. Frances Ann Day, Lesbian and Gay Voices: An Annotated Bibliography and Guide to Literature for Children and Young Adults (Westport, CT: Greenwood Press, 2000).

23. Gerald. P. Mallon and Teresa DeCrescenzo, "Transgender Children and Youth: A Child Welfare Practice Perspective," Child Welfare, 85, no. 2 (2006): 218.

24. Rudolph, Dana. "Where Are the LGBT Biographies for Kids?” Mombian, December 29, 2011, www.mombian.com/ 2011/12/29/where-are-the-lgbt-biographies-for-kids.

25. Pat Griffin and Mathew Ouellett, "From Silence to Safety and Beyond: Historical Trends in Addressing Lesbian, Gay, Bisexual, Transgender Issues in K-12 Schools," Equity \& Excellence in Education 36, no. 2 (2003): 106-14.

26. Kay Emfinger, "Rethinking Welcoming Literacy Environments for LGBT Families," Childhood Education 84, no. 1, (2007): 25. 